\title{
Reexamining the Mechanisms of East Asian Summer Monsoon Changes in Response to Non-East Asian Anthropogenic Aerosol Forcing
}

\author{
ZHILI WANG \\ State Key Laboratory of Severe Weather and Key Laboratory of Atmospheric Chemistry of CMA, Chinese Academy of \\ Meteorological Sciences, Beijing, and Collaborative Innovation Center on Forecast and Evaluation of Meteorological \\ Disasters, Nanjing University of Information Science and Technology, Nanjing, China \\ JUNYU MU \\ State Key Laboratory of Severe Weather and Key Laboratory of Atmospheric Chemistry of CMA, Chinese Academy of \\ Meteorological Sciences, Beijing, China \\ MEILIN YANG \\ Institute of Urban Meteorology, China Meteorological Administration, Beijing, China \\ XIAOCHAO YU \\ State Key Laboratory of Severe Weather and Key Laboratory of Atmospheric Chemistry of CMA, Chinese Academy of \\ Meteorological Sciences, Beijing, China
}

(Manuscript received 20 July 2019, in final form 27 November 2019)

\begin{abstract}
This study examines the mechanisms by which the East Asian summer monsoon (EASM) changes in response to non-East Asian (NEA) anthropogenic aerosol forcing by distinguishing the fast direct atmospheric response and slow ocean-mediated response to forcing using a global aerosol-climate coupled model. The results show that NEA aerosol forcing significantly exacerbates the weakening of the EASM due to local aerosol forcing. The fast response is dominant in the weakening of the EASM and an anomalous precipitation pattern over eastern China resembling the "southern flood and northern drought" pattern in the total response to NEA aerosol forcing. Changes in upper-tropospheric temperature caused by the fast response play a major role in the impact of NEA aerosol forcing on the EASM. Anomalous cooling occurs during summer in the upper troposphere $\left(\right.$ at $\left.\sim 40^{\circ} \mathrm{N}\right)$ over East Asia caused by the fast response. This is due to the combined effects of strong eastward cold advection in the Northern Hemisphere midlatitudes caused by increased aerosol loading in Europe and the resulting change in local meridional heat transport in East Asia. Subsequently, the zonal wind speed changes on either side of the anomalous cooling, and the East Asian subtropical jet shifts equatorward, thereby weakening the EASM. The changes in atmospheric temperature and the local Hadley cell caused by the slow response to NEA aerosol forcing are conducive to strengthening the southwesterly winds over eastern China. Our study suggests the importance of NEA aerosol forcing in driving changes in the EASM on a fast time scale.
\end{abstract}

\section{Introduction}

The East Asian monsoon (EAM) is an important climatological phenomenon (Ding and Chan 2005). Variations in the EAM can cause floods and droughts at the regional scale (Yu et al. 2004), and also affect the global climate due to interactions between the low and midlatitudes and the circumglobal teleconnection (Ding and Wang

Corresponding author: Zhili Wang, wangzl@cma.gov.cn
2005). Climate anomalies due to changes in the EAM can be disastrous, potentially causing huge social economic losses and even endangering human lives (Piao et al. 2010; Auffhammer et al. 2012). Therefore, understanding the mechanisms of the EAM change is important for mitigating climate change disasters.

Atmospheric aerosols can affect the radiation and energy budgets of Earth by directly absorbing and scattering sunlight (Myhre et al. 2013a). Moreover, aerosols can alter cloud microphysics by acting as cloud condensation 
or ice nuclei, thereby affecting climate at the regional and global scales (Boucher et al. 2013). Anthropogenic aerosol forcing has been identified as a primary driver of long-term changes in the East Asian summer monsoon (EASM) since the 1950s (Song et al. 2014; Liu et al. 2019). Several studies showed different impacts of aerosol forcing on the monsoon system through a regional climate model approach (e.g., Ji et al. 2011; Zhuang et al. 2018) compared to the results from a global climate model because of the high resolution and lack of nonlocal aerosol effects. Aerosols emitted from local sources generally only change the regional aerosol burden, and have a negligible effect on the aerosol burden in remote regions due to their relatively short atmospheric lifetime (Dong et al. 2016; Westervelt et al. 2017). Local aerosols can have a large impact on regional temperature, circulation, and precipitation directly by interacting with radiation and clouds (Hodnebrog et al. 2016; Heinzeller et al. 2016; $\mathrm{Li}$ et al. 2016). There have been many studies on the effects of aerosols emitted from local sources on EASM circulation and precipitation, and the relevant mechanisms have been well characterized (e.g., Chen et al. 2016, 2018; Zhuang et al. 2018; Dong et al. 2019).

Some recent studies showed that aerosols emitted from local sources indirectly affected the climate in remote regions by means of large-scale circulation (e.g., Ji et al. 2015; Westervelt et al. 2017; Liu et al. 2018; Persad and Caldeira 2018; Lewinschal et al. 2019). Cowan and Cai (2011) reported that non-Asian anthropogenic aerosol forcing contributes to the suppression of the twentieth-century Asian summer monsoon caused by Asian anthropogenic aerosol forcing. In addition, the increase in both local and remote anthropogenic aerosols has contributed to the weakening of the South Asian summer monsoon seen in the late twentieth century (Bollasina et al. 2014). Q. Wang et al. (2017) noted that anthropogenic aerosol forcing from outside East Asia could exacerbate the weakening of EASM circulation caused by local aerosol forcing in East Asia. Multimodel ensemble simulations from phase 5 of the Coupled Model Intercomparison Program (CMIP5) indicated that global aerosol forcing led to anomalous cyclonic circulation over the northwestern Pacific during the second half of the twentieth century (Song et al. 2014). However, there was anomalous anticyclonic circulation over this region in response to changes in Asian/East Asian anthropogenic aerosols (Chen et al. 2018; Dong et al. 2019). This may reflect the importance of non-East Asian anthropogenic aerosols in the response of the EASM to global aerosol forcing (Dong et al. 2019).

Despite several studies recognizing the impact of nonEast Asian aerosol forcing on the EASM, the underlying mechanisms remain poorly understood. Cowan and Cai (2011) suggested that increases in anthropogenic aerosols from remote sources (predominantly sulfate from Europe) could intensify and broaden the scope of surface cooling in Eurasia induced by increased Asian anthropogenic aerosols, thereby causing significant effects on the Asian summer monsoon. Some studies have shown that the slow response of the ocean to aerosol forcing plays a major role in driving changes in the Asian summer monsoon, by altering upper tropospheric thermodynamics (Ganguly et al. 2012; Z. Wang et al. 2017). However, Li et al. (2018) argued that rapid changes in surface temperature over continental Asia could be more important with respect to the impact of aerosol forcing on the EASM.

This study explores the mechanisms of changes in the EASM in response to non-East Asian anthropogenic aerosol forcing through differentiating the fast direct atmospheric response and slow ocean-mediated response to forcing using a global aerosol-climate coupled model. The total response of the EASM to non-East Asian aerosol forcing from the coupled model has been already demonstrated in Q. Wang et al. (2017) and this study focuses on investigating fast and slow responses and elucidating the physical processes involved. The paper is organized as follows. Section 2 introduces the model, simulations, and overall method. Section 3 shows the changes in upper- and lower-tropospheric land-ocean thermal contrasts in East Asia as well as the dynamic mechanisms underlying EASM changes in the fast and slow responses to non-East Asian aerosol forcing. The main conclusions are summarized and discussed in section 4 . Summer refers to the June-August average in this paper.

\section{Methodology}

\section{a. Model description}

We used a global aerosol-climate model that combined the atmospheric general circulation model of the Beijing Climate Center, version 2.0 (BCC_AGCM2.0), and China Meteorological Administration (CMA) Unified Atmospheric Chemistry Environment for Aerosols (CUACE/Aero), referred to as BCC_AGCM2.0_ CUACE/Aero (Zhang et al. 2012, 2014; Wang et al. 2014). BCC_AGCM2.0 has a horizontal resolution of $2.8^{\circ} \times 2.8^{\circ}$ and 26 vertical levels, with a rigid lid at $2.9 \mathrm{hPa}$ (Wu et al. 2010). The model adopts the new Beijing Climate Center radiation transfer model (BCCRAD) under the cloud overlap scheme of the Monte Carlo independent column approximation (McICA) (Zhang et al. 2014). A two-moment bulk cloud microphysical scheme that predicts both mass and number concentrations of cloud droplets and ice crystals (Morrison and Gettelman 2008) has been integrated into the model (Wang et al. 2014). 
Thus, the model can physically represent aerosol-radiation and aerosol-liquid cloud interactions. The aerosol model CUACE/Aero is a size-segregated multicomponent aerosol module, where the radii of each species of aerosol are divided into 12 bins between 0.005 and $20.48 \mu \mathrm{m}$ (Zhou et al. 2012). The model can simulate the mass concentrations of five tropospheric aerosol species, including sulfate, organic carbon (OC), black carbon (BC), sea salt, and dust. Aerosol processes primarily consist of emission, advection, diffusion, gaseous chemistry, and dry and wet deposition. Dust and BC are assumed to be insoluble, while sulfate, $\mathrm{OC}$, and sea salt are hygroscopic.

BCC_AGCM2.0_CUACE/Aero has been widely used to investigate aerosol radiative forcing (e.g., Zhang et al. 2012; Bond et al. 2013; Myhre et al. 2013b; Wang et al. 2013, 2014) and the resulting climate effects (e.g., Zhang et al. 2016; Voigt et al. 2017; Zhao et al. 2017). The model can reasonably reproduce the geographic distribution and seasonal cycle of aerosol mass concentrations and optical properties (Zhang et al. 2012; Wang et al. 2013, 2014), as well as spatial patterns of surface wind and precipitation in Asian monsoon regions (Q. Wang et al. 2017).

For our analysis, emissions of anthropogenic aerosols and their precursors were taken from Lamarque et al. (2010). Natural emissions of soil dust and sea salt were calculated online. Figure 1 shows the spatial patterns of annual changes in sulfur dioxide $\left(\mathrm{SO}_{2}\right), \mathrm{BC}$, and $\mathrm{OC}$ emissions between 2000 and 1850. East Asia, and especially eastern China, has experienced sharp increases in anthropogenic aerosol emissions of three species since the start of the industrial era, with annual $\mathrm{SO}_{2}$ emissions exceeding $6 \times 10^{-10} \mathrm{~kg} \mathrm{~m}^{-2} \mathrm{~s}^{-1}$, and annual $\mathrm{BC}$ and $\mathrm{OC}$ emissions exceeding $6 \times 10^{-11} \mathrm{~kg} \mathrm{~m}^{-2} \mathrm{~s}^{-1}$ over most of this region. However, there have also been significant increases in $\mathrm{SO}_{2}$ emissions in western Europe, eastern North America, and South Asia, and large increases in $\mathrm{BC}$ and OC emissions over central Africa and South America, South Asia, and parts of western Europe.

\section{b. Simulations}

The climate response to prescribed forcing can be characterized as a combination of fast and slow responses (Andrews et al. 2010). The fast response is regarded as a direct atmospheric response to aerosol forcing due to changes in radiation, cloud physics, atmospheric heating rate, and land surface characteristics. The slow response is regarded as a response to aerosol-forced sea surface temperature (SST) changes arising from atmosphereocean interaction. As summarized in Table 1, climate response to non-East Asian aerosol forcing on different time scales can be separated through a set of simulations. Such decomposition can provide useful insight into the effect of non-East Asian aerosol forcing on the EASM.
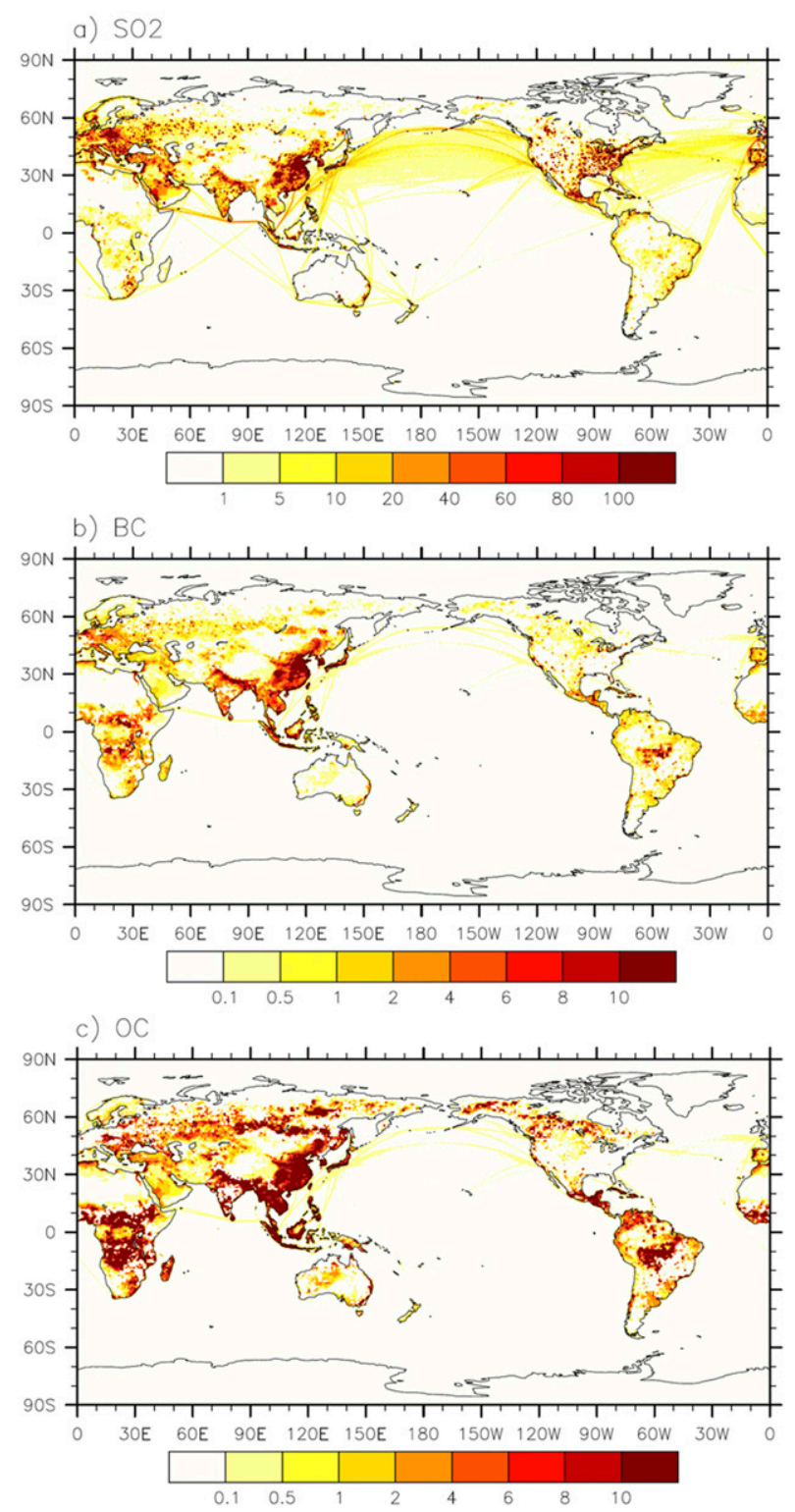

FIG. 1. Spatial patterns of annual changes in (a) $\mathrm{SO}_{2}$, (b) $\mathrm{BC}$, and (c) OC emissions between 2000 and $1850\left(10^{-11} \mathrm{~kg} \mathrm{~m}^{-2} \mathrm{~s}^{-1}\right)$. Data are from Lamarque et al. (2010).

First, we performed four simulations using the aerosolclimate model BCC_AGCM2.0_CUACE/Aero coupled with a slab-ocean model. The model settings were the same in all simulations, except in terms of aerosol emissions. The greenhouse gas concentrations were fixed at year 2000 levels in each simulation. As a control case (referred to as PI), emissions levels for all aerosols from the year 1850 were used. In the second simulation (referred to as PD), all aerosol emissions were kept at year 2000 levels. In the third simulation (referred to as PDNEA), the aerosol emissions outside East Asia were kept at year 2000 levels, but those 
TABLE 1. Simulation setups.

\begin{tabular}{lcc}
\hline \hline Simulation & \multicolumn{1}{c}{ Aerosol emissions } & Ocean \\
\hline PI & Year $1850 \mathrm{SO}_{2}, \mathrm{BC}$, and OC & Slab-ocean model \\
PD & Year 2000 $\mathrm{SO}_{2}, \mathrm{BC}$, and OC & Slab-ocean model \\
PDNEA & Year $1850 \mathrm{SO}_{2}, \mathrm{BC}$, and OC & Slab-ocean model \\
& within East Asia, but year & \\
& 2000 $\mathrm{SO}_{2}, \mathrm{BC}$, and OC & \\
& outside East Asia & \\
PDEA & Year 2000 $\mathrm{SO}_{2}, \mathrm{BC}$, and OC & Slab-ocean model \\
& within East Asia, but year & \\
& 1850 $\mathrm{SO}_{2}, \mathrm{BC}$, and OC & \\
PIF & outside East Asia & \\
PDNEAF & As in PI & Fixed SST from PI \\
& As in PDNEA & Fixed SST from PI
\end{tabular}

within East Asia were fixed at year 1850 levels. In the fourth simulation (referred to as PDEA), the aerosol emissions in East Asia at year 2000 levels were used, but those outside East Asia were fixed at year 1850 levels. We define East Asia as the region bounded by $0^{\circ}-50^{\circ} \mathrm{N}, 100^{\circ}-140^{\circ} \mathrm{E}$. Each simulation was run for 80 years, with the last 50 years constituting our analysis period. These simulations replicate those of Q. Wang et al. (2017). The total responses of the EASM to global, East Asian, and non-East Asian aerosol forcing between 2000 and 1850 were obtained from the four simulations, respectively. The total responses have been investigated in Q. Wang et al. (2017) and Fig. 2 herein is replicated from Q. Wang et al. (2017).

Second, we repeated the PI and PDNEA simulations, but replaced the slab-ocean model with the climatological monthly mean SST and sea ice cover data output by the PI simulation (referred to as PIF and PDNEAF, respectively). Each simulation was run for 30 years, with only the last 20 years being analyzed. Removing ocean feedback allowed us to obtain the fast response of the EASM to non-East Asian aerosol forcing in these simulations.

Finally, we approximated the slow response of the EASM to non-East Asian aerosol forcing by subtracting the fast response from the total response. Previous studies have suggested that such decomposition works well for determining the response of the Asian summer monsoon to aerosol forcing, although its nonlinearity is not negligible (Hsieh et al. 2013; Li et al. 2018).

\section{Results}

\section{a. Non-East Asian aerosol forcing and the resulting total response of the EASM}

Figure 2 shows the distributions of change in aerosol optical depth (AOD) at $550 \mathrm{~nm}$ and effective shortwave
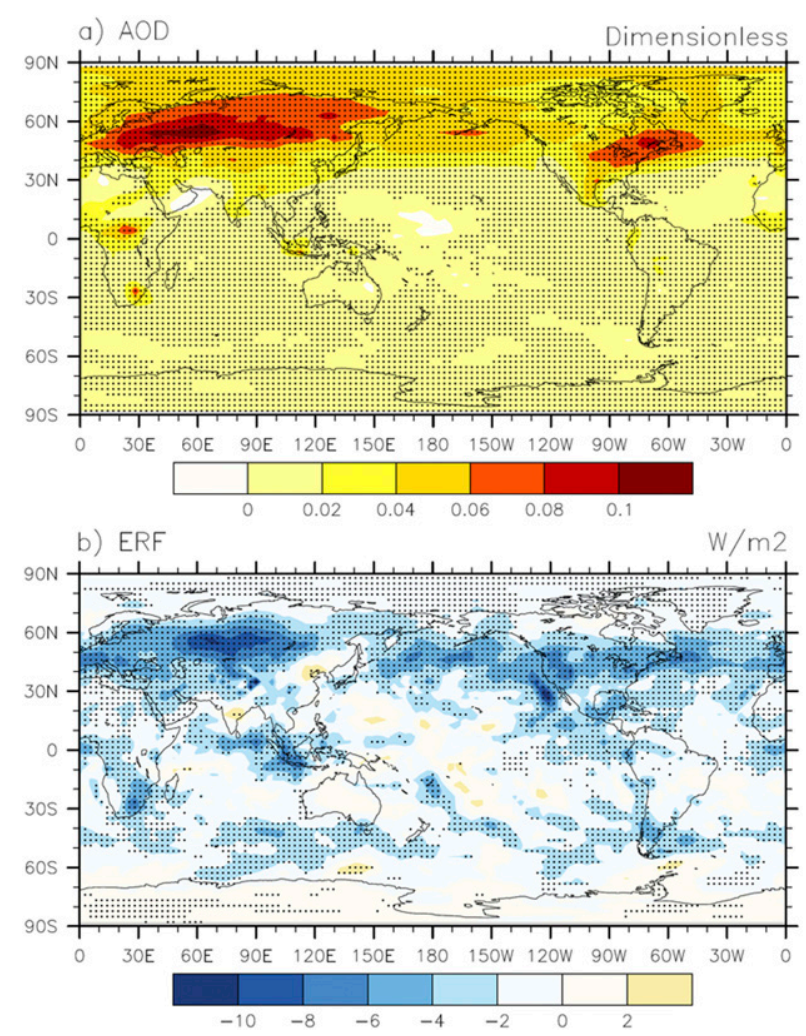

FIG. 2. Spatial patterns of annual mean (a) change in aerosol optical depth at $550 \mathrm{~nm}$ (dimensionless) and (b) effective radiative forcing in shortwave region ( $\mathrm{W} \mathrm{m}^{-2}$ ) caused by the changes in nonEast Asian anthropogenic aerosol emissions. The stippled areas represent significance at $\geq 95 \%$ confidence level using the $t$ test.

radiative forcing caused by the changes in non-East Asian anthropogenic aerosol emissions. The spatial pattern of change in AOD (Fig. 2a) is similar to that in $\mathrm{SO}_{2}$ emissions (Fig. 1a), except in East Asia. This implies that the change in sulfate loading may play a key role in the changes of non-East Asian anthropogenic aerosols. Large increases in AOD appear over Europe, eastern North America, and their downstream regions, with values generally ranging from 0.04 to 0.12 . This is mainly attributed to the significant increase in sulfate concentrations over those regions (Fig. 2 of Q. Wang et al. 2017). The pattern and magnitude of changes in AOD are in good agreement with those in Kirkevåg et al. (2008) and Lamarque et al. (2010). However, changes in non-East Asian anthropogenic aerosols only have a weak impact on AOD over East Asia (Fig. 2a).

Accordingly, large negative effective radiative forcing (ERF) appears over Europe, eastern North America, and the northern Pacific and Atlantic, with values larger than $-4 \mathrm{~W} \mathrm{~m}^{-2}$ in most of these regions. This is most likely due to the direct interaction of aerosols with radiation and clouds (Fig. 2b). There is no statistically 

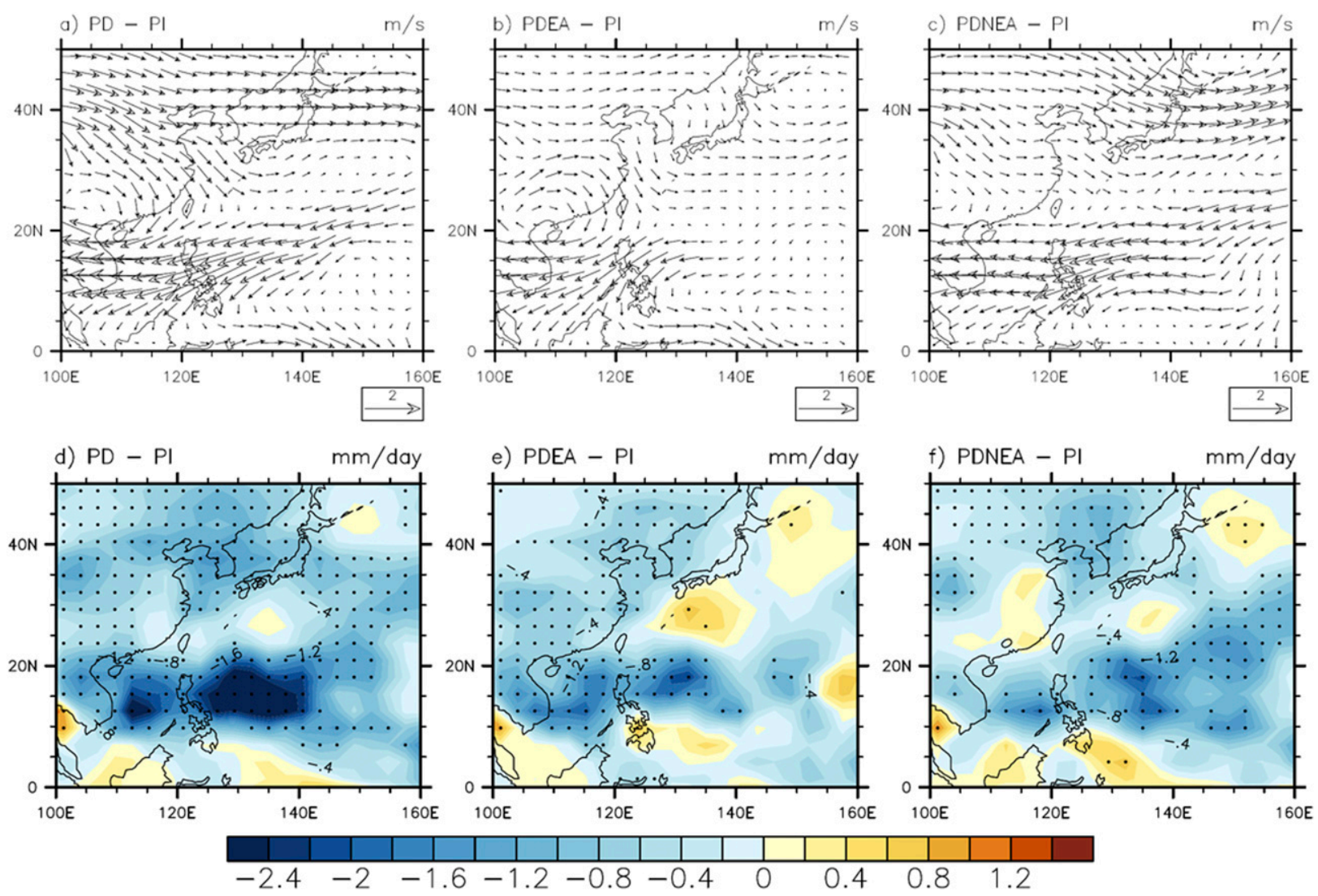

FIG. 3. Changes in (a)-(c) wind vectors at $850 \mathrm{hPa}\left(\mathrm{m} \mathrm{s}^{-1}\right)$ and (d)-(f) precipitation ( $\left.\mathrm{mm} \mathrm{day}^{-1}\right)$ during summer in the total response to (left) global, (middle) East Asian, and (right) non-East Asian anthropogenic aerosol forcing. The stippled areas represent significance at $\geq 95 \%$ confidence level using the $t$ test.

significant ERF over almost the entire East Asian monsoon region (EAMR). Small positive ERF appears in North China, related to the decrease in low cloud cover in this area (figure not shown). These analyses indicate that aerosol transportation into East Asia from remote sources is rare, thereby having only a small direct effect on radiation fluxes. This supports the results of Dong et al. (2016), who explored the influence of European $\mathrm{SO}_{2}$ emissions on East Asian climate.

Figure 3 depicts the changes in wind vectors at $850 \mathrm{hPa}$ and precipitation during summer in the total response to global, East Asian, and non-East Asian anthropogenic aerosol forcing. As suggested by Song et al. (2014) and Q. Wang et al. (2017), global aerosol forcing leads to anomalous northerly winds in summer over eastern China and surrounding oceans (Fig. 3a), indicating that the EASM circulation is weakened. This results in a decrease in precipitation rate over most of the EAMR (Fig. 3d). The largest decrease occurs over the oceans between $10^{\circ}$ and $20^{\circ} \mathrm{N}$, with the maximum being $-2.4 \mathrm{~mm} \mathrm{day}^{-1}$. There are also decreases in precipitation rate of more than $0.8 \mathrm{~mm} \mathrm{day}^{-1}$ in large parts of northern China.
As seen from Figs. $3 \mathrm{~b}$ and $3 \mathrm{c}$, non-East Asian aerosol forcing significantly intensifies the weakening of the EASM circulation caused by East Asian aerosol forcing, and even has a larger impact on the EASM north of $30^{\circ} \mathrm{N}$ and over the South China Sea. Q. Wang et al. (2017) showed that the EASM index was decreased by $7.1 \%$ and $6.2 \%$, respectively, due to nonEast Asian and East Asian aerosol forcings. The local and remote aerosol forcing contributes to the comparable reductions in precipitation in northern China and between $10^{\circ}$ and $20^{\circ} \mathrm{N}$, with values generally more than $-0.4 \mathrm{~mm} \mathrm{day}^{-1}$, but they lead to opposing patterns of precipitation change in eastern China south of $35^{\circ} \mathrm{N}$; the former decreases precipitation while the latter increases it, with the absolute values of changes ranging from 0.2 to $0.4 \mathrm{~mm} \mathrm{day}^{-1}$ (Figs. 3e,f). The magnitude of precipitation decrease in northern China in response to non-East Asian aerosol forcing is comparable to the observed change during the second half of the twentieth century, but the precipitation increase in southern China is less than the observed change (Song et al. 2014). 
a) Fast

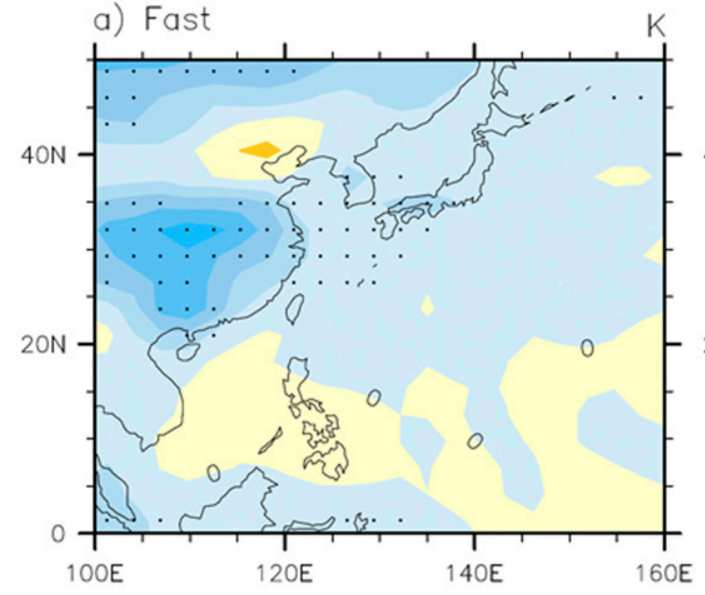

b) Slow

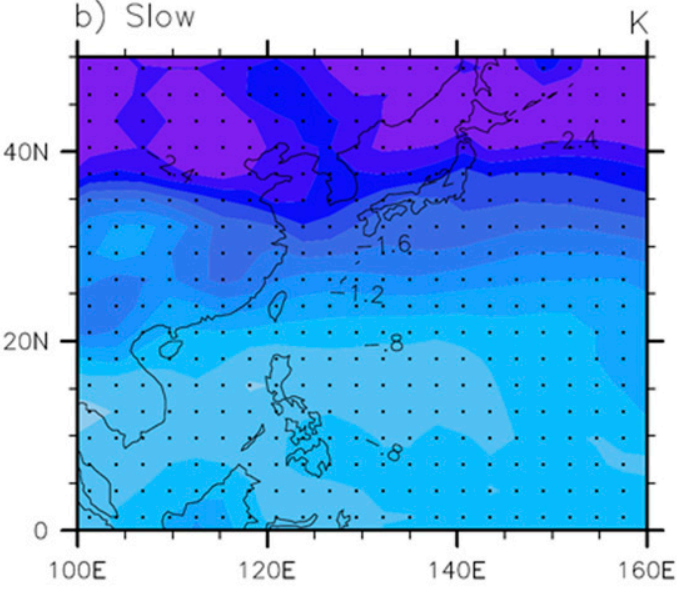

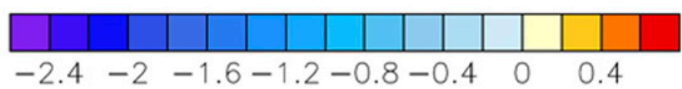
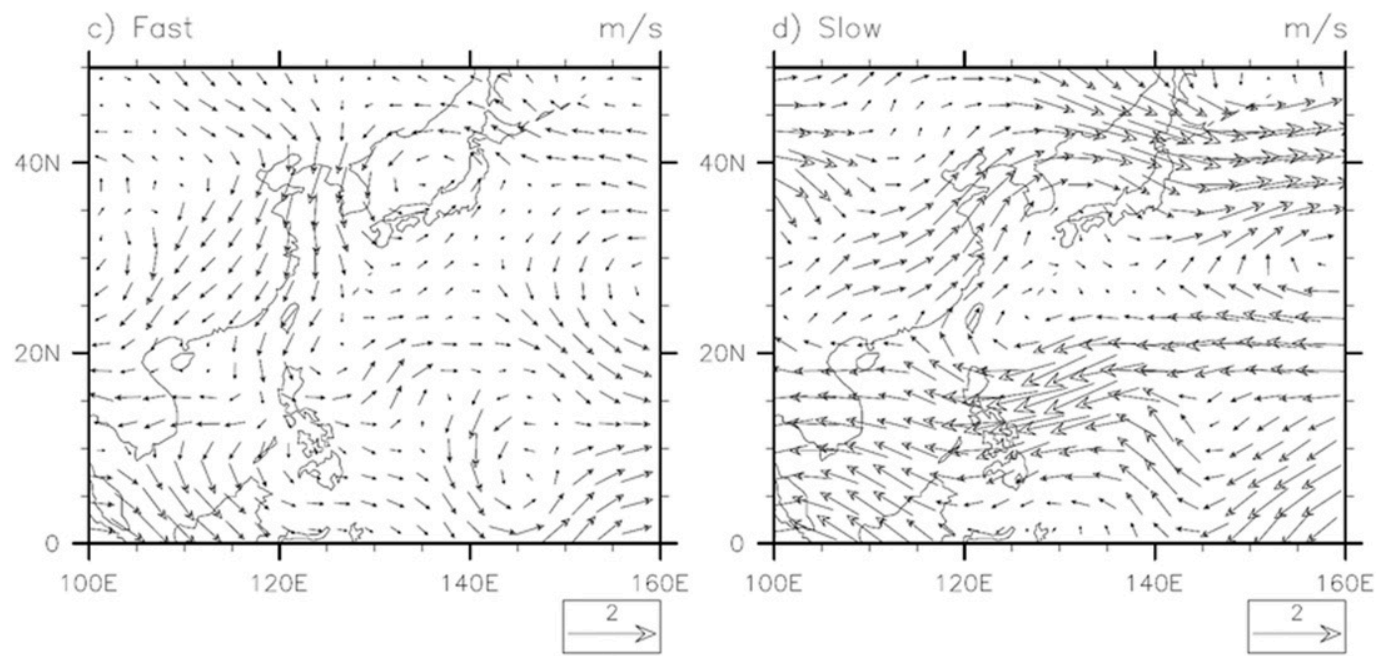

FIG. 4. Changes in (a),(b) surface air temperature (K) and (c),(d) wind vectors at $850 \mathrm{hPa}\left(\mathrm{m} \mathrm{s}^{-1}\right)$ during summer in the (left) fast and (right) slow responses to non-East Asian anthropogenic aerosol forcing. The stippled areas represent significance at $\geq 95 \%$ confidence level using the $t$ test.

Next, we discuss how the anthropogenic aerosols from remote sources have such a large impact on the EASM, even though they only have minor effects on aerosol burdens and radiation fluxes in East Asia. Total response of the EASM to non-East Asian aerosol forcing has been already demonstrated in Q. Wang et al. (2017) and this study focuses on investigating fast and slow responses and elucidating the physical processes involved.

\section{b. Fast and slow responses of the EASM to non-East Asian aerosol forcing}

Figure 4 shows the changes in surface air temperature and wind vectors at $850 \mathrm{hPa}$ during summer in the fast and slow responses to non-East Asian aerosol forcing. The decomposition of fast and slow responses has been used in many studies to understand the mechanisms underlying the climate response to forcing (e.g., Ganguly et al. 2012; Hsieh et al. 2013; Z. Wang et al. 2017; Li et al. 2018; Zhao and Suzuki 2019). Q. Wang et al. (2017) showed that significant surface cooling appears in summer in the total response to non-East Asian aerosol forcing, and increases with latitude over the EAMR, with a temperature decrease of more than $2 \mathrm{~K}$ north of $40^{\circ} \mathrm{N}$. The slow response is dominant in the surface cooling over the EAMR in the total response to non-East Asian aerosol forcing, with the largest cooling reaching $-2.4 \mathrm{~K}$ (Fig. 4). The midlatitude surface cooling in the slow response (Fig. $4 \mathrm{~b}$ ) is primarily caused by the change in radiation flux (Fig. 10a) associated with aerosol-induced cloud feedbacks (Chung and Soden 2017; Persad and Caldeira 2018) and change in 


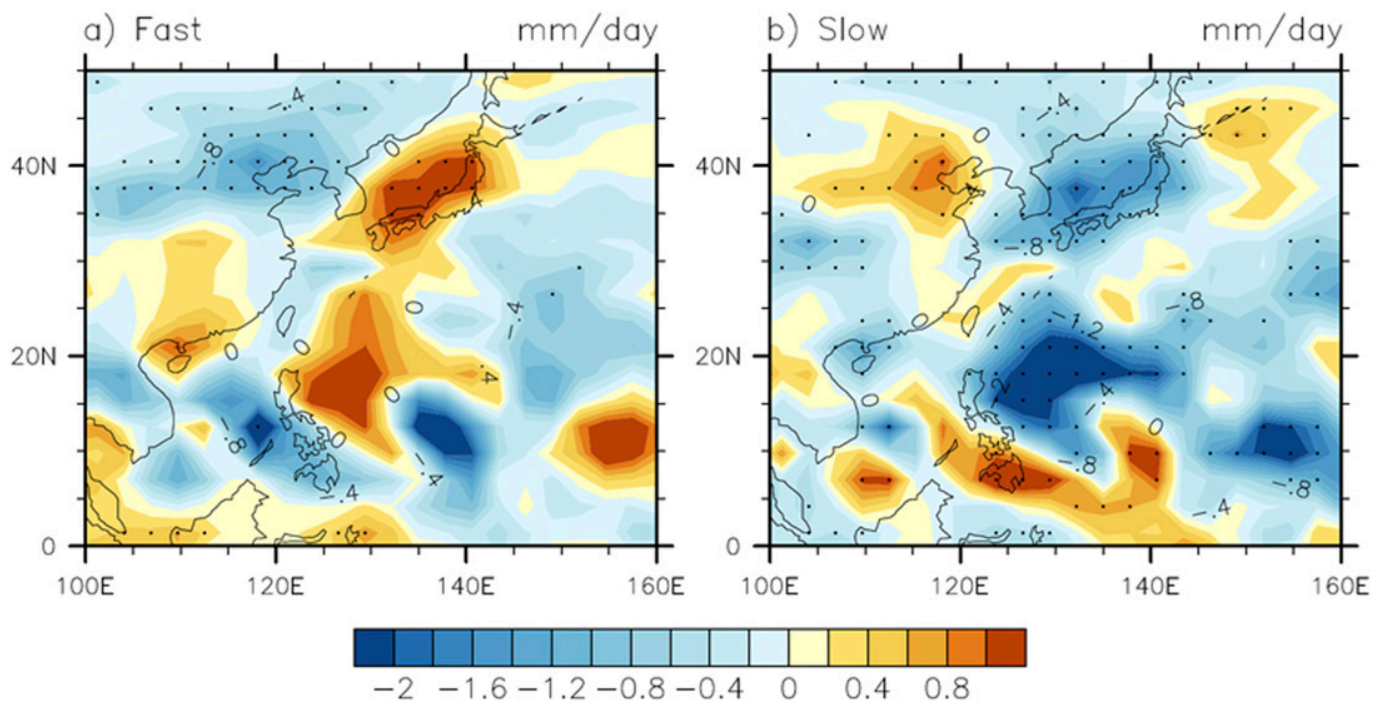

FIG. 5. Change in precipitation rate $\left(\mathrm{mm} \mathrm{day}^{-1}\right)$ during summer in the (a) fast and (b) slow responses to non-East Asian anthropogenic aerosol forcing. The stippled areas represent significance at $\geq 95 \%$ confidence level using the $t$ test.

large-scale atmospheric circulation (Wang et al. 2019). Unexpectedly, however, the slow response enhances the southwesterly wind in eastern China and nearby oceans (Fig. 4d), although it appears to significantly decrease the ocean-land surface thermal contrast in East Asia (Fig. 4b). The slow response causes large anomalies in easterly flow over the tropical western Pacific, which is responsible for the overall weakening of the EASM over this region (Fig. 3c). Considerably less surface cooling over continental East Asia is attributable to the fast response than the slow response (Fig. 4a). The regional averaged decreases in surface temperatures over East Asia $\left(0^{\circ}-50^{\circ} \mathrm{N}, 100^{\circ}-140^{\circ} \mathrm{E}\right)$ in the fast and slow responses are -0.15 and $-1.4 \mathrm{~K}$, respectively. However, the fast response leads to remarkable northerly wind anomalies in eastern China and downstream regions (Fig. 4c). This effect is dominant in the context of the overall weakening of the EASM. Similar results have also been found when considering the effect of global aerosol forcing ( $\mathrm{Li}$ et al. 2018).

The response of EASM precipitation to non-East Asian aerosol forcing on different time scales (Fig. 5) is very consistent with the response of circulation. The changes in precipitation due to the fast and slow responses are almost entirely opposite in East Asia, aside from some areas in the northwest Pacific. The fast response is dominant over continental East Asia, showing an anomalous pattern of precipitation over eastern China resembling the "southern flood and northern drought" pattern, with maximum changes of +0.8 and $-1.2 \mathrm{~mm} \mathrm{day}^{-1}$, respectively (Fig. 5a). The slow response is responsible for the decrease in precipitation rate over most of the northwest Pacific, with the largest reduction exceeding $2 \mathrm{~mm} \mathrm{day}^{-1}$ (Fig. 5b).

\section{c. Dynamic mechanisms underlying EASM changes}

Differential heating of land and ocean over Asia due to solar radiation is a primary driver of the Asian monsoon (Ding and Chan 2005; Dai et al. 2013). The ocean-land surface thermal contrast in the EAMR is reduced in the fast response to non-East Asian aerosol forcing (Fig. 4a), but the extent of the decrease seems inadequate to explain such a noticeable weakening of the EASM (Fig. 4c). Dai et al. (2013) suggested that the ocean-land thermal contrast in the upper troposphere $(200-500 \mathrm{hPa})$ in East Asia plays a dominant role in driving the EASM circulation relative to that in the lower troposphere $(500-850 \mathrm{hPa})$. Following Dai et al. (2013), we used changes in geopotential heights to calculate changes in upper- and lower-tropospheric oceanland thermal contrasts during summer in East Asia in the fast and slow responses to non-East Asian aerosol forcing (Table 2). The spatial patterns of changes in upper- and lower-tropospheric mean geopotential heights during summer over East Asia in the fast and slow responses are shown in Fig. 6. The changes in north-south and west-east thermal contrasts correspond to changes in the zonal wind averaged over the region bounded by $10^{\circ}-30^{\circ} \mathrm{N}, 105^{\circ}-125^{\circ} \mathrm{E}$ and meridional wind averaged over the region bounded by $20^{\circ}-40^{\circ} \mathrm{N}, 110^{\circ}-130^{\circ} \mathrm{E}$, respectively.

The north-south thermal contrasts in the upper and lower troposphere in East Asia are decreased in the fast response, but the change in the upper troposphere is 7 
TABLE 2. Changes in north-south and west-east ocean-land thermal contrasts in the upper $(200-500 \mathrm{hPa})$ and lower $(500-$ $850 \mathrm{hPa}$ ) troposphere during summer over East Asia in the fast and slow responses to non-East Asian aerosol forcing. The negative and positive values represent the decrease and increase of thermal contrast, respectively. The south-north and west-east contrasts are defined as $Z_{\left(20^{\circ}-40^{\circ} \mathrm{N}, 105^{\circ}-125^{\circ} \mathrm{E}\right)}-Z_{\left(10^{\circ} \mathrm{S}-10^{\circ} \mathrm{N}, 105^{\circ}-125^{\circ} \mathrm{E}\right)}$ and $Z_{\left(20^{\circ}-40^{\circ} \mathrm{N}, 105^{\circ}-120^{\circ} \mathrm{E}\right)}-Z_{\left(10^{\circ} \mathrm{S}-10^{\circ} \mathrm{N}, 135^{\circ}-150^{\circ} \mathrm{E}\right)}$, respectively (Dai et al. 2013), where $Z$ is geopotential height.

\begin{tabular}{lcrrrr}
\hline \hline & \multicolumn{2}{c}{ North-south contrast } & & \multicolumn{2}{c}{ West-east contrast } \\
\cline { 2 - 3 } & Upper & Lower & & Upper & Lower \\
\hline Fast & -7.7 & -1.1 & & -2.7 & 3.0 \\
Slow & -3.9 & 1.7 & & 4.6 & -1.5 \\
\hline
\end{tabular}

times larger than that in the lower troposphere $(-7.7$ vs -1.1$)$. The changes in west-east thermal contrasts between the upper and lower troposphere in the fast response are comparable, but these have opposite signs $(-2.7 \mathrm{vs} 3.0)$, and the former is in agreement with the change of EASM circulation (Fig. 4c). Regarding the slow response, an increase of 4.6 in upper-tropospheric west-east ocean-land thermal contrast is the main reason for the enhanced southerlies over eastern China, while a decrease of 3.9 in upper-tropospheric northsouth thermal contrast reflects weakened westerlies over the oceans to the south of China (Fig. 4d). In summary, the change in ocean-land thermal contrast in the upper troposphere over East Asia plays a decisive role in the response of the EASM to non-East Asian aerosol forcing, supporting the findings of Dai et al. (2013).

Figure 7 shows the changes in atmospheric temperature averaged between $30^{\circ}$ and $50^{\circ} \mathrm{N}$ and between $100^{\circ}$ and $130^{\circ} \mathrm{E}$ during summer in the fast response to nonEast Asian aerosol forcing. The fast climate response results in cooling throughout almost the whole troposphere, with two significant cooling zones being particularly evident. The first lies between $30^{\circ}$ and $80^{\circ} \mathrm{E}$ in the Northern Hemisphere $(\mathrm{NH})$ midlatitudes, with a large cooling maxima of more than $-0.8 \mathrm{~K}$ in the upper troposphere (Fig. 7a). The second is located in the mid- to upper troposphere over East Asia $\left(30^{\circ}-50^{\circ} \mathrm{N}, 100^{\circ}-\right.$ $130^{\circ} \mathrm{E}$ ), centered around $40^{\circ} \mathrm{N}$ at $300 \mathrm{hPa}$, with values ranging from -0.4 to $-0.9 \mathrm{~K}$ (Fig. $7 \mathrm{~b}$ ). The first cooling zone is primarily attributed to the decrease in solar fluxes at the surface caused by the increased anthropogenic aerosols in Europe (Fig. 2) and the resulting changes in meridional atmospheric heat transport due to changes in local meridional circulation (Fig. 8a). The decrease in northward atmospheric heat transport reaches $-160 \mathrm{~K} \mathrm{~m} \mathrm{~s}^{-1}$ around $40^{\circ} \mathrm{N}$ between 200 and $300 \mathrm{hPa}$. It is well known that westerly airflow prevails during summer in the $\mathrm{NH}$ midlatitudes, especially in the upper troposphere. Cowan and Cai (2011) reported that surface cooling in western Europe caused by the increased non-Asian sulfate loadings could be extended markedly in the zonal direction due to advection by westerly winds. Our results show that such an extension is more prominent in the upper troposphere in the fast response to non-East Asian aerosol forcing. With the strong westerly jets, the large amount of cooling in the upper troposphere between $30^{\circ}$ and $80^{\circ} \mathrm{E}$ in the $\mathrm{NH}$ midlatitudes leads to significant eastward cold advection at these altitudes (Fig. 7a). This partially contributes to the decrease in upper-tropospheric temperature in subtropical East Asia. Figure 7a shows that only a weak cooling occurs at about $90^{\circ} \mathrm{E}$ between two large cooling zones. This is because that $90^{\circ} \mathrm{E}$ is the location of the Tibetan Plateau (TP). As an elevated heat source, the TP leads to strong ascent locally and divergence in the upper troposphere during summer. The eastward cold advection from Europe cannot be gathered over there, and the elevated heating also partially offsets the cold advection.

The cooling in the upper troposphere modifies the local meridional circulation over East Asia in the fast response, in turn causing a change in local meridional heat transport. There is clear southward cold advection in the upper troposphere for the midlatitudes of East Asia, with the magnitudes generally being over $40 \mathrm{~K} \mathrm{~m} \mathrm{~s}^{-1}$ (Fig. 8b). The combined effect of these two factors contributes to anomalous cooling in the upper troposphere in subtropical East Asia, with the largest temperature decrease being $0.9 \mathrm{~K}$ at $300 \mathrm{hPa}$ around $40^{\circ} \mathrm{N}$ (Fig. 7b). This is also the main reason why the upper-tropospheric ocean-land thermal contrast during summer over East Asia is decreased in the fast response to non-East Asian aerosol forcing (Table 2). In addition, our results show that eastward cold advection in the lower atmosphere from Europe may have no direct impact on the lower atmospheric temperature in East Asia due to blocking by the Tibetan Plateau (Fig. 7a). This is consistent with the findings of Dong et al. (2016), who report that sulfate increases in Europe have no significant effect on surface temperature over the EAMR, but lead to rapid midtropospheric cooling during summer in East Asia.

The East Asian subtropical jet (EASJ) located at $200 \mathrm{hPa}$ around $40^{\circ} \mathrm{N}$ is a crucial component of the EASM. Southward and northward shifts of the EASJ signify weakening and strengthening of the EASM, respectively (Yu et al. 2004). The mid- to upper-tropospheric cooling in East Asia leads to a clear decrease in geopotential height at the same tropospheric levels in the fast response to non-East Asian aerosol forcing (Fig. 9a). Geopotential height decreases by over $28 \mathrm{~m}$ at $200 \mathrm{hPa}$ around $40^{\circ} \mathrm{N}$. As a result, an anomalous low 
Upper Troposphere
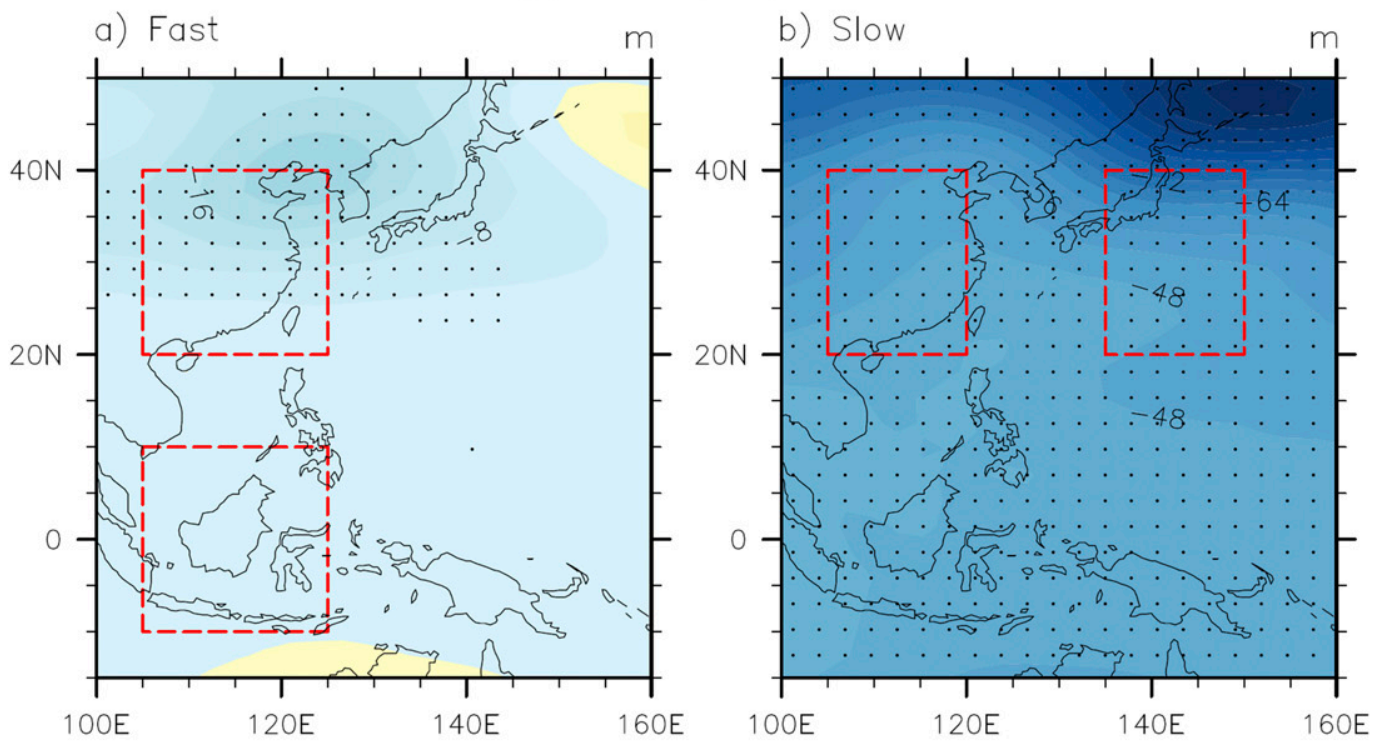

Lower Troposphere
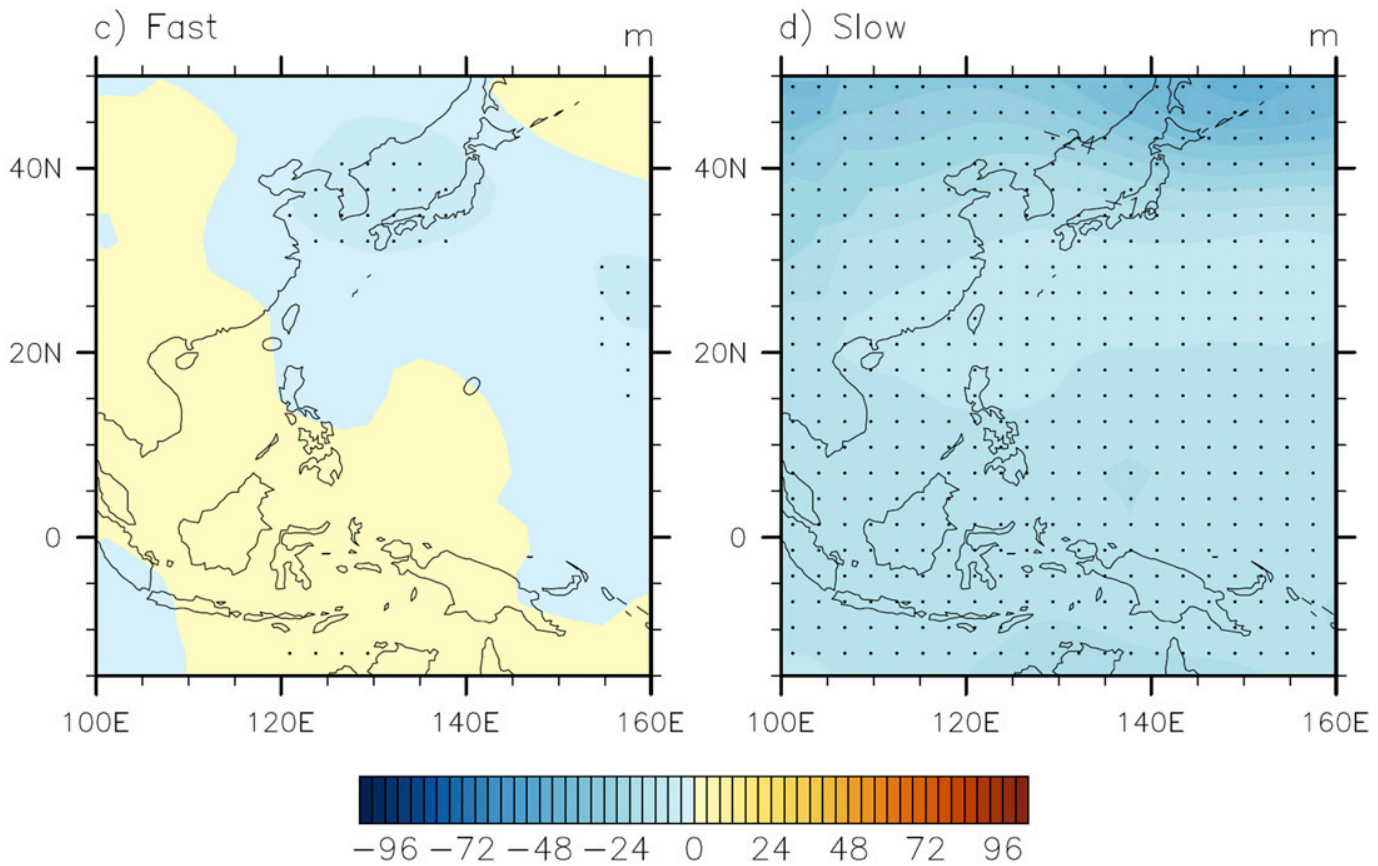

FIG. 6. Spatial patterns of changes in upper- and lower-tropospheric mean geopotential heights $(\mathrm{m})$ during summer over East Asia in the (a),(c) fast and (b),(d) slow responses to non-East Asian anthropogenic aerosol forcing. The four rectangular boxes in (a) and (b) indicate the averaging areas for the calculation of thermal contrasts. The stippled areas represent significance at $\geq 95 \%$ confidence level using the $t$ test.

pressure center forms in the upper troposphere near $40^{\circ} \mathrm{N}$. This increases the equatorward and poleward pressure gradient force to the north and south of the cooling region, respectively (Z. Wang et al. 2017). Such changes in pressure gradient force cause a decrease (increase) in westerlies to the north (south) of the EASJ (Fig. 9b), according to geostrophic balance between the Coriolis force and pressure gradient force. The largest changes in westerlies at $200 \mathrm{hPa}$ reach -1 and $+2 \mathrm{~m} \mathrm{~s}^{-1}$, respectively. Consequently, the EASJ is displaced equatorward in the fast response to non-East Asian aerosol forcing. The changes in zonal wind speed 


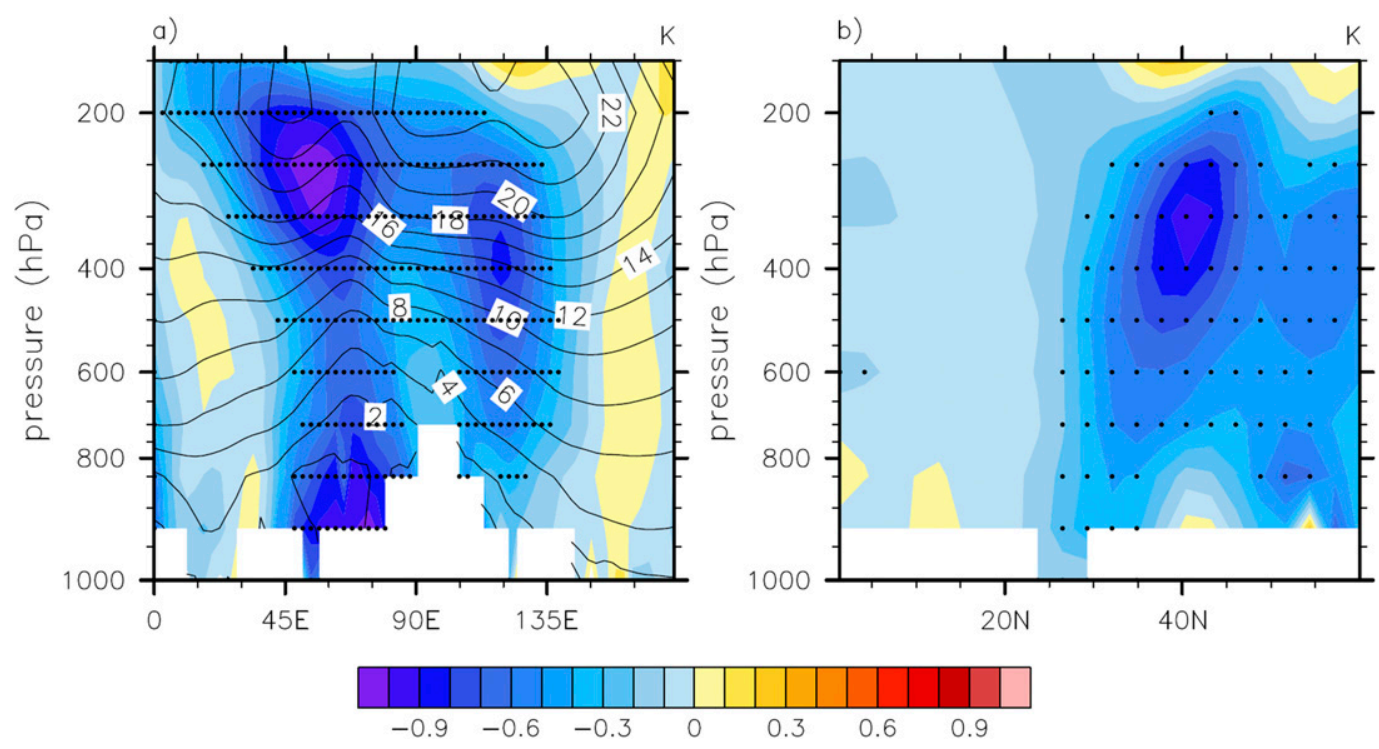

FIG. 7. Changes in (a) meridionally averaged atmospheric temperature between $30^{\circ}$ and $50^{\circ} \mathrm{N}$ (shaded) and (b) zonally averaged atmospheric temperature between $100^{\circ}$ and $130^{\circ} \mathrm{E}$ during summer in the fast response to nonEast Asian anthropogenic aerosol forcing (K). The contour line in (a) is the climatological summer mean zonal winds in PIF and the positive value indicates westerly $\left(\mathrm{m} \mathrm{s}^{-1}\right)$. The stippled areas represent significance at $\geq 95 \%$ confidence level using the $t$ test.

of the two flanks of the EASJ cause anomalous cyclonic vorticity in the upper troposphere for the midlatitudes of East Asia (Fig. 9c). The anomalous cyclone enhances the subsidence beneath it, with the change in vertical velocity being more than $0.01 \mathrm{~Pa} \mathrm{~s}^{-1}$ at $40^{\circ} \mathrm{N}$ (Fig. 9d). The strong subsidence leads to an anomalous anticyclone in the lower atmosphere over eastern China and the surrounding oceans. To the east of the anticyclone, anomalous northerly wind increases ( $\mathrm{Yu}$ et al. 2004). Finally, the EASM circulation is weakened, with a decrease of $0.38 \mathrm{~m} \mathrm{~s}^{-1}$ in southerly wind speed at $850 \mathrm{hPa}$ averaged over $\left(20^{\circ}-40^{\circ} \mathrm{N}, 100^{\circ}-130^{\circ} \mathrm{E}\right)$ (Fig. $\left.4 \mathrm{c}\right)$.

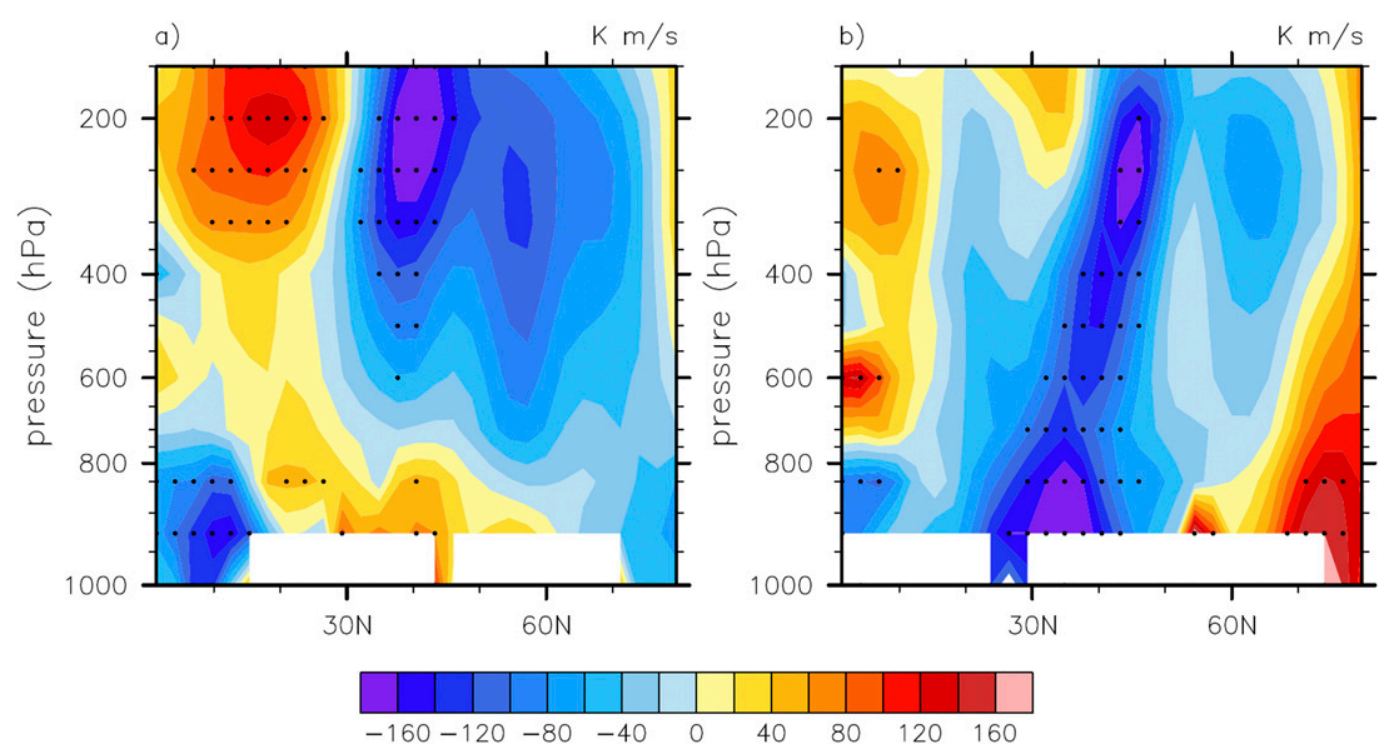

FIG. 8. Changes in zonally averaged atmospheric heat transport by mean circulation ( $v T$; the positive value represents northward transport; $\mathrm{K} \mathrm{m} \mathrm{s}^{-1}$ ) (a) between $30^{\circ}$ and $70^{\circ} \mathrm{E}$ and (b) between $100^{\circ}$ and $130^{\circ} \mathrm{E}$ during summer in the fast response to non-East Asian anthropogenic aerosol forcing. The stippled areas represent significance at $\geq 95 \%$ confidence level using the $t$ test. 

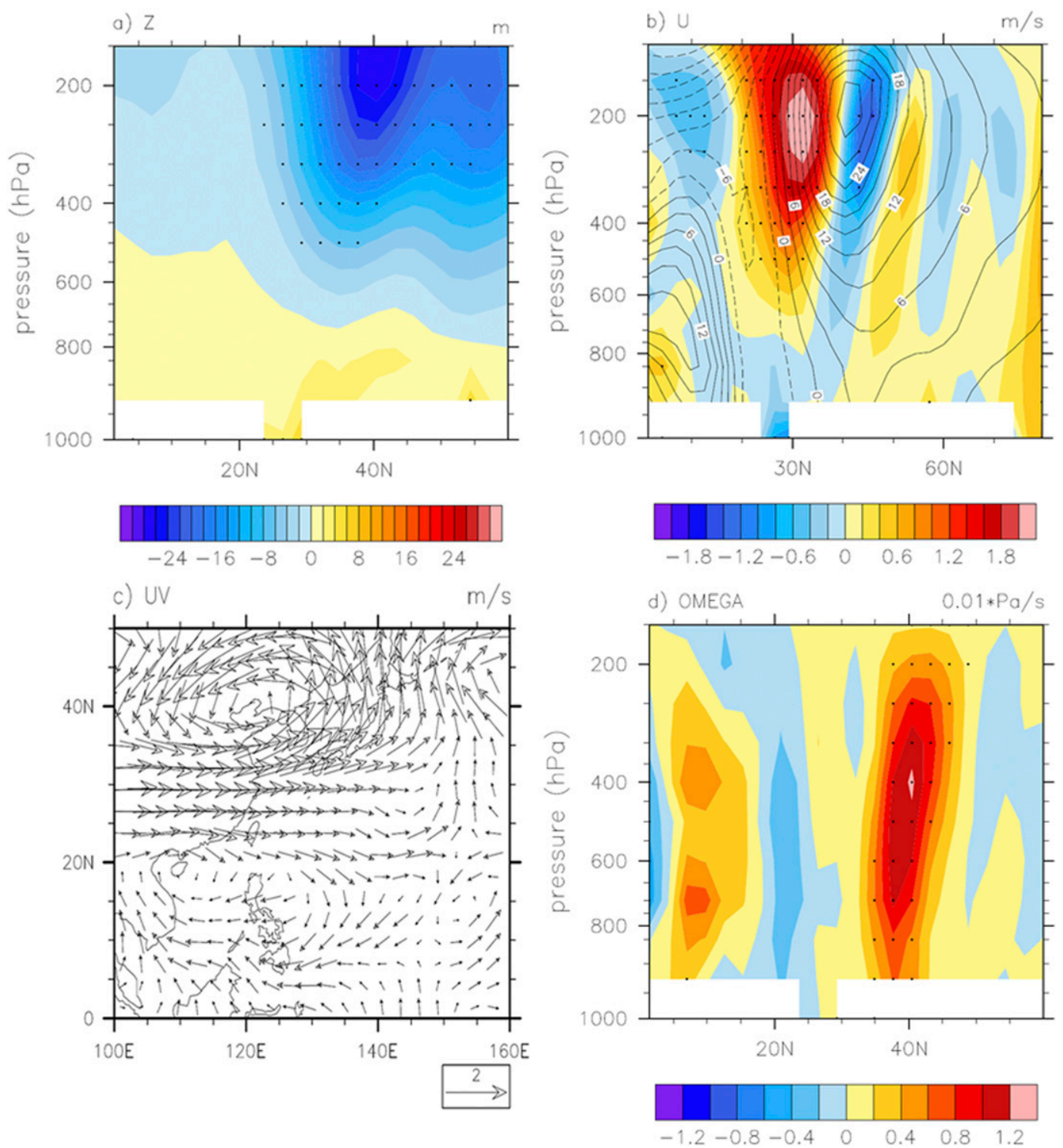

FIG. 9. Changes in zonally averaged (a) geopotential height $(\mathrm{m})$ and $(\mathrm{b})$ zonal wind (shaded; $\mathrm{m} \mathrm{s}^{-1}$ ) between $100^{\circ}$ and $130^{\circ} \mathrm{E}$, (c) wind vectors at $200 \mathrm{hPa}\left(\mathrm{m} \mathrm{s}^{-1}\right)$, and (d) zonally averaged vertical velocity between $100^{\circ}$ and $130^{\circ} \mathrm{E}$ (the positive value represents descend motion; $10^{-2} \mathrm{~Pa} \mathrm{~s}^{-1}$ ) during summer in the fast response to non-East Asian anthropogenic aerosol forcing. The dashed and solid lines in (b) represent the climatological summer mean easterly and westerly winds in PIF, respectively. The stippled areas represent significance at $\geq 95 \%$ confidence level using the $t$ test.

The weakening of the EASM leads to an anomalous precipitation pattern in summer over eastern China resembling the southern flood and northern drought pattern (Fig. 5a). Convergence in the upper troposphere in subtropical East Asia due to the anomalous cyclone can further intensify the cooling in this region. The downward transport of cold air due to the anomalous sinking motion and the weakened transport of moisture in the lower atmosphere from the southern oceans due to anomalous northerlies may be the primary reasons for surface cooling over eastern China (Fig. 4a). The anomalous descents are also associated with anomalous adiabatic warming.

Aerosols in the atmosphere affect temperature when interacting with radiation, both directly and via aerosols' fast impacts on cloud amount and radiative properties. These interactions with radiation then change the energy balance at the top of the atmosphere (TOA), which induces a temperature change mediated by a series of feedback processes (Persad and Caldeira 2018). 
Figure 10 shows the spatial patterns of changes in net radiation flux at the TOA and SST during summer in the total response to non-East Asian aerosol forcing. There is a significant decrease in net radiation flux at the TOA in the mid and high latitudes of the $\mathrm{NH}$, especially with values larger than $-10 \mathrm{~W} \mathrm{~m}^{-2}$ over most of the North Pacific (Fig. 10a), due to the cloud feedbacks and surface albedo feedbacks driven by sea ice changes (Chung and Soden 2017; Persad and Caldeira 2018). This results in a significant decrease in SST over those latitudes, with the largest value exceeding $-4 \mathrm{~K}$ (Fig. 10b). Consequently, a deep troposhperic cooling in the mid- and high latitudes of the NH in the slow response (Fig. 11a) appears due to the interaction between ocean and atmosphere and the resulting change in large-scale atmospheric circulation.

There is more significant tropospheric cooling in summer in the slow response to non-East Asian aerosol forcing versus the fast response (Fig. 11a). However, the pattern of cooling attributable to the slow response is substantially different from that attributable to the fast response. Large tropospheric cooling appears north of $50^{\circ} \mathrm{N}$ in the slow response, with the largest decrease in temperature being over $2.4 \mathrm{~K}$. The upper-tropospheric cooling produces a clear decrease in geopotential height north of $50^{\circ} \mathrm{N}$. There is an anomalous low center of geopotential height at $200 \mathrm{hPa}$ around $60^{\circ} \mathrm{N}$, with the largest decrease exceeding $100 \mathrm{~m}$ (Fig. 11b). As a result, there is a northward pressure gradient force and an increase in westerly flow in the upper troposphere in the midlatitudes of East Asia in the slow response (Fig. 11c). The maximum increase of more than $2 \mathrm{~m} \mathrm{~s}^{-1}$ in westerly wind speed occurs between $40^{\circ}$ and $50^{\circ} \mathrm{N}$. Such changes in zonal winds in the upper troposphere result in a northward shift of the EASJ and anomalous ascent around $40^{\circ} \mathrm{N}$, with the change in vertical velocity exceeding $-0.004 \mathrm{~Pa} \mathrm{~s}^{-1}$ at this latitude (Fig. 11d). These contribute to the enhancement of southwesterly wind during summer over eastern China in the slow response (Fig. 4d). However, the fast response to non-East Asian aerosol forcing is dominant with respect to the displacement of the EASJ (Figs. 9b and 11c). The southward trend of the EASJ and rainfall anomaly caused by the non-East Asian aerosol forcing are consistent with the observed shift of the EASJ and change in precipitation over eastern China (Yu et al. 2004).

Previous studies have suggested that the larger surface cooling in the $\mathrm{NH}$ due to aerosol forcing requires a cross-equatorial Hadley cell to offset the interhemispheric energy imbalance in the atmosphere (Ocko et al. 2014; Wang et al. 2016). Our results show that non-East Asian aerosol forcing leads to a significant interhemispheric asymmetric adjustment in SST $(-1.1 \mathrm{~K}$ in the $\mathrm{NH}$ vs $-0.6 \mathrm{~K}$ in the Southern Hemisphere; Fig. 10b).
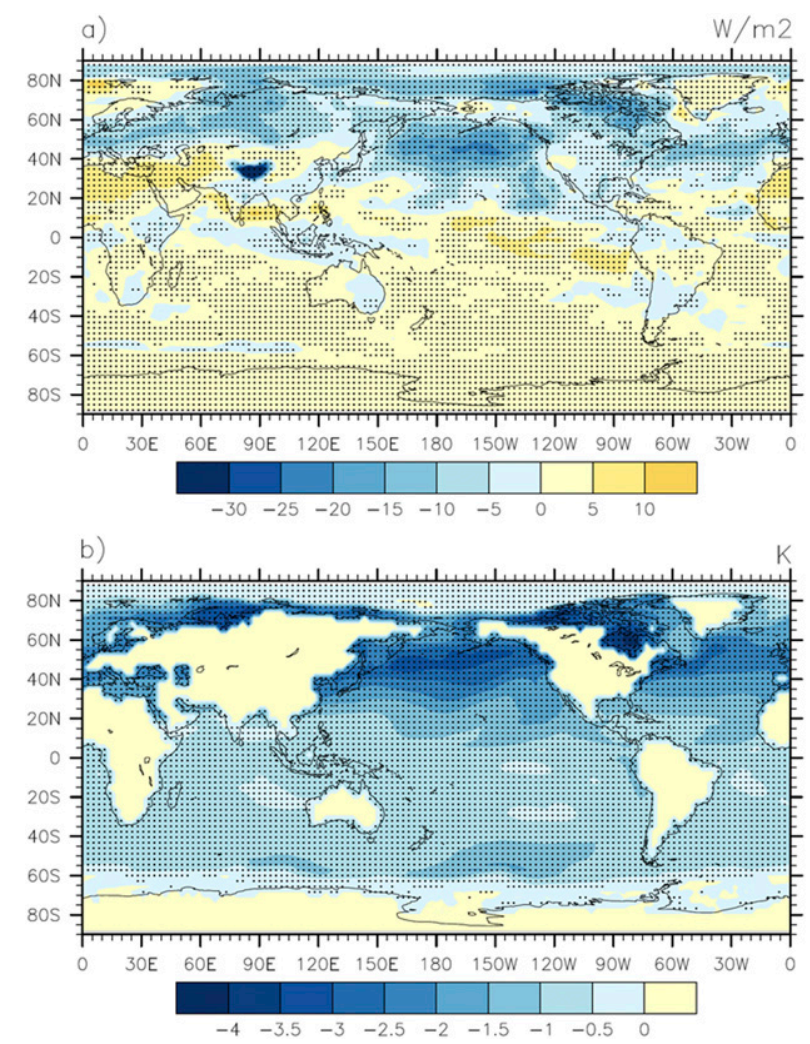

FIG. 10. Spatial patterns of changes in (a) net radiation flux at the top of the atmosphere $\left(\mathrm{W} \mathrm{m}^{-2}\right)$ and (b) sea surface temperature (K) during summer in the total response to non-East Asian anthropogenic aerosol forcing. The stippled areas represent significance at $\geq 95 \%$ confidence level using the $t$ test.

Hence, an anomalous local Hadley cell in the NH tropics appears in the slow response to non-East Asian aerosol forcing (Fig. 11d). This anomaly results in a significant descent of more than $0.002 \mathrm{~Pa} \mathrm{~s}^{-1}$ and anomalous anticyclonic circulation in the lower atmosphere at around $20^{\circ} \mathrm{N}$ in East Asia (Fig. 11d). Consequently, the southwesterly wind during summer in southeastern China is further strengthened, while the westerly flow over the tropical oceans is weakened in the slow response (Fig. 4d).

In brief, both the displacement of the EASJ caused by the deep tropospheric cooling in the mid- and high latitudes of East Asia and the anomalous Hadley cell caused by the interhemispheric asymmetric change in surface temperature in the slow response to non-East Asian aerosol forcing contributes to an enhancement of southwesterly wind during summer in eastern China, with an increase of $0.21 \mathrm{~m} \mathrm{~s}^{-1}$ in southerly wind speed at $850 \mathrm{hPa}$ averaged over $20^{\circ}-40^{\circ} \mathrm{N}, 100^{\circ}-130^{\circ} \mathrm{E}$ (Fig. $4 \mathrm{~d}$ ). The cooling in the mid- and high latitudes and interhemispheric asymmetric change in surface temperature result from change in aerosol emissions not only over 

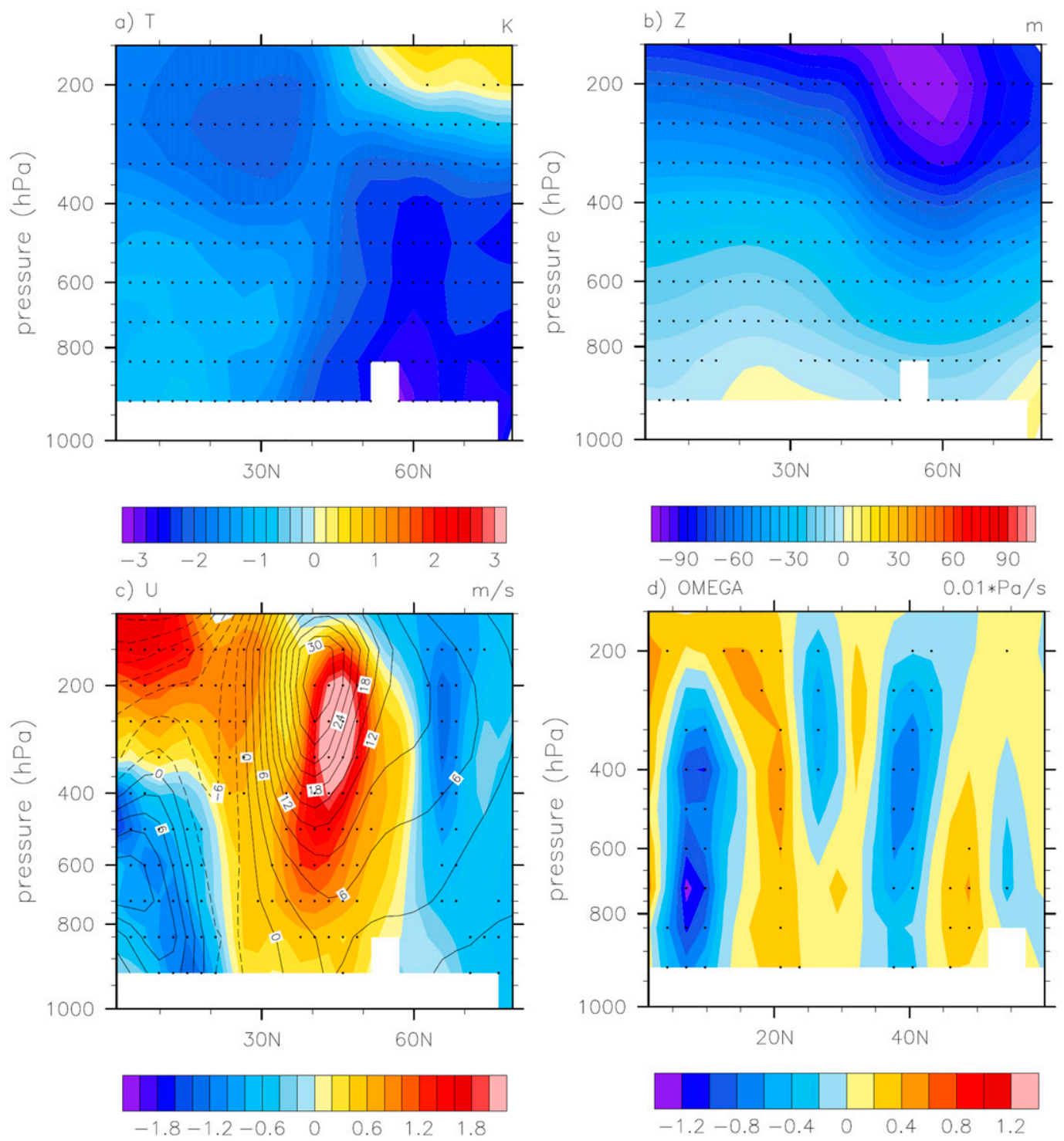

FIG. 11. Changes in zonally averaged (a) temperature (K), (b) geopotential height (m), (c) zonal wind (shaded; $\mathrm{m} \mathrm{s}^{-1}$ ), and (d) vertical velocity (the positive value represents descend motion; $10^{-2} \mathrm{~Pa} \mathrm{~s}^{-1}$ ) between $100^{\circ}$ and $130^{\circ} \mathrm{E}$ during summer in the slow response to non-East Asian anthropogenic aerosol forcing. The dashed and solid lines in (c) represent the climatological summer mean easterly and westerly winds in PI, respectively. The stippled areas represent significance at $\geq 95 \%$ confidence level using the $t$ test.

Europe, but also from other regions, such as the United States (Persad and Caldeira 2018).

\section{Summary and conclusions}

Although several studies have identified the impact of remote aerosol forcing on the EASM (e.g., Cowan and Cai 2011; Dong et al. 2016; Q. Wang et al. 2017), the potential mechanisms are still poorly understood. This study examines the mechanisms of the EASM response to non-East Asian aerosol forcing using simulations based on the global aerosol-climate coupled model BCC_AGCM2.0_CUACE/Aero. Total response of the EASM to non-East Asian aerosol forcing from the coupled model has been already demonstrated in Q. Wang et al. (2017) and this study focuses on investigating fast and slow responses and elucidating the physical processes involved. Our results suggest that increased anthropogenic aerosol emissions outside East Asia only lead to slight perturbations of aerosol burdens and radiation fluxes in East Asia. However, non-East Asian aerosol forcing significantly intensifies the weakening of 
the EASM caused by East Asian aerosol forcing, and even has larger effects on circulation and precipitation in some regions, as suggested Q. Wang et al. (2017).

The fast response to non-East Asian aerosol forcing is dominant with respect to the weakening of the EASM, and to an anomalous precipitation pattern seen in summer over eastern China resembling the so-called southern flood and northern drought phenomenon. However, the southwesterly flow over eastern China is enhanced in the slow response to non-East Asian aerosol forcing, which partially compensates for the weakening of the EASM in the fast response. The slow response is responsible for the decrease in precipitation over most of the northwest Pacific. The decrease in ocean-land thermal contrasts in the upper troposphere over East Asia in the fast response plays a crucial role in the effect of non-East Asian aerosol forcing on the EASM, consistent with the results of Dai et al. (2013).

The combined effect of significant eastward cold advection in the upper troposphere in the $\mathrm{NH}$ midlatitudes caused by the increased aerosol loadings in Europe and the resulting change in local meridional heat transport over East Asia produces an anomalous cooling center in the upper troposphere at around $40^{\circ} \mathrm{N}$ over East Asia, attributable to the fast response. This combined effect is the main reason for the decrease in upper-tropospheric ocean-land thermal contrasts over East Asia in the fast response. The anomalous cooling center in the upper troposphere leads to changes in zonal wind speed on either side and a southward shift of the EASJ, ultimately weakening the EASM circulation (Yu et al. 2004; Z. Wang et al. 2017). This finding differs from that in Cowan and Cai (2011), who suggested that non-Asian aerosol forcing suppressed the Asian summer monsoon by enhancing and widening the scope of surface cooling over Asia due to the local aerosol forcing. However, our result is similar to that reported by Dong et al. (2016), who indicated that European sulfate loading could rapidly weaken the EASM by cooling the midtroposphere over East Asia.

The pattern of change in atmospheric temperature in the slow response is different to that in the fast response to non-East Asian aerosol forcing. The EASJ shifts northward and the southwesterly flow is increased in the lower atmosphere during summer over eastern China in the slow response. In addition, the interhemispheric asymmetric surface cooling associated with the slow response causes an anomalous Hadley cell in East Asia, which further enhances the EASM in southeastern China.

This study highlights the importance of non-East Asian aerosol forcing in driving changes of the EASM on a fast time scale, which occur via alteration of the thermodynamic structure of the upper troposphere. This type of fast climate response may have major consequences for the economy and ecosystems (Persad et al. 2018). Understanding the effect of non-East Asian aerosol forcing is also important for attributing and predicting the change of the EASM. Previous studies have suggested that anthropogenic aerosol forcing is likely the primary driver of the interdecadal weakening of the EASM seen after the 1950s (e.g., Song et al. 2014; Liu et al. 2019; Wang et al. 2019). However, the EASM showed a recovery in the 1990s (Song et al. 2014), despite anthropogenic aerosol emissions in East Asia continuing to increase after the 1950s. Our study implies that the rapid decline of sulfate burden in Europe (Lamarque et al. 2010) is very likely to have contributed to the recovery of the EASM during that period.

Acknowledgments. This study was supported by the National Key Research and Development Program of China (Grant 2017YFA0603503) and the National Natural Science Foundation of China (Grants 41875179 and 41575139).

\section{REFERENCES}

Andrews, T., P. M. Forster, O. Boucher, N. Bellouin, and A. Jones, 2010: Precipitation, radiative forcing and global temperature change. Geophys. Res. Lett., 37, L14701, https:// doi.org/10.1029/2010GL043991.

Auffhammer, M., V. Ramanathan, and J. R. Vincent, 2012: Climate change, the monsoon, and rice yield in India. Climatic Change, 111, 411-424, https://doi.org/10.1007/s10584-011-0208-4.

Bollasina, M. A., Y. Ming, V. Ramaswamy, M. D. Schwarzkopf, and V. Naik, 2014: Contribution of local and remote anthropogenic aerosols to the twentieth century weakening of the South Asian monsoon. Geophys. Res. Lett., 41, 680-687, https://doi.org/10.1002/2013GL058183.

Bond, T. C., and Coauthors, 2013: Bounding the role of black carbon in the climate system: A scientific assessment. J. Geophys. Res. Atmos., 118, 5380-5552, https://doi.org/10.1002/jgrd.50171.

Boucher, O., and Coauthors, 2013: Clouds and aerosols. Climate Change 2013: The Physical Science Basis, T. F. Stocker et al., Eds., Cambridge University Press, 571-657.

Chen, G., W. Wang, and J. Chen, 2018: Circulation responses to regional aerosol climate forcing in summer over East Asia. Climate Dyn., 51, 3973-3984, https://doi.org/10.1007/s00382018-4267-3.

Chen, J., I. Chen, and I. Tsai, 2016: Dynamic feedback of aerosol effects on the East Asian summer monsoon. J. Climate, 29, 6137-6149, https://doi.org/10.1175/JCLI-D-15-0758.1.

Chung, E.-S., and B. J. Soden, 2017: Hemispheric climate shifts driven by anthropogenic aerosol-cloud interactions. Nat. Geosci., 10, 566-571, https://doi.org/10.1038/ngeo2988.

Cowan, T., and W. Cai, 2011: The impact of Asian and non-Asian anthropogenic aerosols on 20th century Asian summer monsoon. Geophys. Res. Lett., 38, L11703, https://doi.org/10.1029/ 2011 GL047268.

Dai, A., H. Li, Y. Sun, L.-C. Hong, LinHo, C. Chou, and T. Zhou, 2013: The relative roles of upper and lower tropospheric thermal contrasts and tropical influences in driving Asian 
summer monsoons. J. Geophys. Res. Atmos., 118, 7024 7045, https://doi.org/10.1002/jgrd.50565.

Ding, Q. H., and B. Wang, 2005: Circumglobal teleconnection in the Northern Hemisphere summer. J. Climate, 18, 3483-3505, https://doi.org/10.1175/JCLI3473.1.

Ding, Y. H., and C. L. Chan, 2005: The East Asian summer monsoon: An overview. Meteor. Atmos. Phys., 89, 117-142, https:// doi.org/10.1007/s00703-005-0125-z.

Dong, B., R. T. Sutton, E. J. Highwood, and L. J. Wilcox, 2016: Preferred response of the East Asian summer monsoon to local and non-local anthropogenic sulphur dioxide emissions. Climate Dyn., 46, 1733-1751, https://doi.org/10.1007/s00382015-2671-5.

— L. J. Wilcox, E. J. Highwood, and R. T. Sutton, 2019: Impacts of recent decadal changes in Asian aerosols on the East Asian summer monsoon: Roles of aerosol-radiation and aerosolcloud interactions. Climate Dyn., 53, 3235-3256, https:// doi.org/10.1007/s00382-019-04698-0.

Ganguly, D., P. J. Rasch, H. Wang, and J. Yoon, 2012: Fast and slow responses of the South Asian monsoon system to anthropogenic aerosols. Geophys. Res. Lett., 39, L18804, https:// doi.org/10.1029/2012GL053043.

Heinzeller, D., W. Junkermann, and H. Kunstmann, 2016: Anthropogenic aerosol emissions and rainfall decline in southwestern Australia: Coincidence or causality? J. Climate, 29, 8471-8493, https://doi.org/10.1175/JCLI-D-16-0082.1.

Hodnebrog, Ø., G. Myhre, P. M. Forster, J. Sillmann, and B. H. Samset, 2016: Local biomass burning is a dominant cause of the observed precipitation reduction in southern Africa. Nat. Commun., 7, 11236, https://doi.org/10.1038/ ncomms11236.

Hsieh, W.-C., W. D. Collins, Y. Liu, J. C. H. Chiang, C.-L. Shie, K. Caldeira, and L. Cao, 2013: Climate response due to carbonaceous aerosols and aerosol-induced SST effects in NCAR Community Atmospheric Model CAM3.5. Atmos. Chem. Phys., 13, 7489-7510, https://doi.org/10.5194/acp-137489-2013.

Ji, Z., S. Kang, D. Zhang, C. Zhu, J. Wu, and Y. Xu, 2011: Simulation of the anthropogenic aerosols over South Asia and their effects on Indian summer monsoon. Climate Dyn., 36, 1633-1647, https://doi.org/10.1007/s00382-010-0982-0.

,-- Z Z. Cong, Q. Zhang, and T. Yao, 2015: Simulation of carbonaceous aerosols over the Third Pole and adjacent regions: Distribution, transportation, deposition, and climatic effects. Climate Dyn., 45, 2831-2846, https://doi.org/10.1007/ s00382-015-2509-1.

Kirkevåg, A., T. Iversen, Ø. Seland, J. B. Debernard, T. Storelvmo, and J. E. Kristjánsson, 2008: Aerosol-cloud-climate interactions in the climate model CAM-Oslo. Tellus, 60A, 492-512, https://doi.org/10.1111/j.1600-0870.2007.00313.x.

Lamarque, J.-F., and Coauthors, 2010: Historical (1850-2000) gridded anthropogenic and biomass burning emissions of reactive gases and aerosols: Methodology and application. Atmos. Chem. Phys., 10, 7017-7039, https://doi.org/10.5194/ acp-10-7017-2010.

Lewinschal, A., A. M. L. Ekman, H.-C. Hansson, M. Sand, T. K. Berntsen, and J. Langner, 2019: Local and remote temperature response of regional $\mathrm{SO}_{2}$ emissions. Atmos. Chem. Phys., 19, 2385-2403, https://doi.org/10.5194/acp-19-23852019.

Li, X., M. Ting, and D. E. Lee, 2018: Fast adjustments of the Asian summer monsoon to anthropogenic aerosols. Geophys. Res. Lett., 45, 1001-1010, https://doi.org/10.1002/2017GL076667.
Li, Z., and Coauthors, 2016: Aerosol and monsoon climate interactions over Asia. Rev. Geophys., 54, 866-929, https://doi.org/ 10.1002/2015RG000500.

Liu, L., and Coauthors, 2018: A PDRMIP multimodel study on the impacts of regional aerosol forcings on global and regional precipitation. J. Climate, 31, 4429-4447, https:// doi.org/10.1175/JCLI-D-17-0439.1.

Liu, Y., and Coauthors, 2019: Anthropogenic aerosols cause recent pronounced weakening of Asian summer monsoon relative to last four centuries. Geophys. Res. Lett., 46, 5469-5479, https:// doi.org/10.1029/2019GL082497.

Morrison, H., and A. Gettelman, 2008: A new two-moment bulk stratiform cloud microphysics scheme in the Community Atmosphere Model, version 3 (CAM3). Part I: Description and numerical tests. J. Climate, 21, 3642-3659, https://doi.org/ 10.1175/2008JCLI2105.1.

Myhre, G., and Coauthors, 2013a: Anthropogenic and natural radiative forcing. Climate Change 2013: The Physical Science Basis, T. F. Stocker et al., Eds., Cambridge University Press, 659-740.

, and Coauthors, 2013b: Radiative forcing of the direct aerosol effect from AeroCom Phase II simulations. Atmos. Chem. Phys., 13, 1853-1877, https://doi.org/10.5194/acp-13-1853-2013.

Ocko, I. B., V. Ramaswamy, and Y. Ming, 2014: Contrasting climate responses to the scattering and absorbing features of anthropogenic aerosol forcings. J. Climate, 27, 5329-5345, https://doi.org/10.1175/JCLI-D-13-00401.1.

Persad, G. G., and K. Caldeira, 2018: Divergent global-scale temperature effects from identical aerosols emitted in different regions. Nat. Commun., 9, 3289, https://doi.org/ 10.1038/s41467-018-05838-6.

—, Y. Ming, Z. Shen, and V. Ramaswamy, 2018: Spatially similar surface energy flux perturbations due to greenhouse gases and aerosols. Nat. Commun., 9, 3247, https://doi.org/ 10.1038/s41467-018-05735-y.

Piao, S., and Coauthors, 2010: The impacts of climate change on water resources and agriculture in China. Nature, 467, 43-51, https://doi.org/10.1038/nature09364.

Song, F., T. Zhou, and Y. Qian, 2014: Responses of East Asian summer monsoon to natural and anthropogenic forcings in the 17 latest CMIP5 models. Geophys. Res. Lett., 41, 596-603, https://doi.org/10.1002/2013GL058705.

Voigt, A., and Coauthors, 2017: Fast and slow shifts of the zonalmean intertropical convergence zone in response to an idealized anthropogenic aerosol. J. Adv. Model. Earth Syst., 9, 870-892, https://doi.org/10.1002/2016MS000902.

Wang, H., S.-P. Xie, and Q. Liu, 2016: Comparison of climate response to anthropogenic aerosol versus greenhouse gas forcing: Distinct patterns. J. Climate, 29, 5175-5188, https:// doi.org/10.1175/JCLI-D-16-0106.1.

Wang, Q., Z. Wang, and H. Zhang, 2017: Impact of anthropogenic aerosols from global, East Asian, and non-East Asian sources on East Asian summer monsoon system. Atmos. Res., 183, 224-236, https://doi.org/10.1016/j.atmosres.2016.08.023.

Wang, Z., H. Zhang, J. Li, X. Jing, and P. Lu, 2013: Radiative forcing and climate response due to the presence of black carbon in cloud droplets. J. Geophys. Res. Atmos., 118, 36623675, https://doi.org/10.1002/JGRD.50312.

, — , and P. Lu, 2014: Improvement of cloud microphysics in the aerosol-climate model BCC_AGCM2.0.1_CUACE/Aero, evaluation against observations, and updated aerosol indirect effect. J. Geophys. Res. Atmos., 119, 8400-8417, https:// doi.org/10.1002/2014JD021886. 
— L. Lin, M. Yang, Y. Xu, and J. Li, 2017: Disentangling fast and slow responses of the East Asian summer monsoon to reflecting and absorbing aerosol forcings. Atmos. Chem. Phys., 17, 11 075-11 088, https://doi.org/10.5194/acp-17-11075-2017.

, — - - - and Z. Guo, 2019: The role of anthropogenic aerosol forcing in interdecadal variations of summertime uppertropospheric temperature over East Asia. Earth's Future, 7, 136-150, https://doi.org/10.1029/2018EF001052.

Westervelt, D. M., and Coauthors, 2017: Multimodel precipitation responses to removal of U.S. sulfur dioxide emissions. J. Geophys. Res. Atmos., 122, 5024-5038, https://doi.org/ 10.1002/2017JD026756.

Wu, T., and Coauthors, 2010: The Beijing Climate Center atmospheric general circulation model: Description and its performance for the present-day climate. Climate Dyn., 34, 123-147, https://doi.org/10.1007/s00382-008-0487-2.

Yu, R., B. Wang, and T. Zhou, 2004: Tropospheric cooling and summer monsoon weakening trend over East Asia. Geophys. Res. Lett., 31, L22212, https://doi.org/10.1029/2004GL021270.

Zhang, H., and Coauthors, 2012: Simulation of direct radiative forcing of aerosols and their effects on East Asian climate using an interactive AGCM-aerosol coupled system. Climate Dyn., 38, 1675-1693, https://doi.org/10.1007/s00382-011-1131-0.

_ X. Jing, and J. Li, 2014: Application and evaluation of a new radiation code under McICA scheme in BCC_AGCM2.0.1.
Geosci. Model Dev., 7, 737-754, https://doi.org/10.5194/gmd-7737-2014.

_- S. Zhao, Z. Wang, X. Zhang, and L. Song, 2016: The updated effective radiative forcing of major anthropogenic aerosols and their effects on global climate at present and in the future. Int. J. Climatol., 36, 4029-4044, https://doi.org/ $10.1002 /$ joc. 4613 .

Zhao, S., and K. Suzuki, 2019: Differing impacts of black carbon and sulfate aerosols on global precipitation and the ITCZ location via atmosphere and ocean energy perturbations. J. Climate, 32, 5567-5582, https://doi.org/10.1175/JCLI-D18-0616.1.

—, H. Zhang, Z. Wang, and X. Jing, 2017: Simulating the effects of anthropogenic aerosols on terrestrial aridity using an aerosol-climate coupled model. J. Climate, 30, 7451-7463, https://doi.org/10.1175/JCLI-D-16-0407.1.

Zhou, C., and Coauthors, 2012: Towards the improvements of simulating the chemical and optical properties of Chinese aerosols using an online coupled model-CUACE/Aero. Tellus, 64B, 18965, https://doi.org/10.3402/tellusb.v64i0.18965.

Zhuang, B., S. Li, T. Wang, J. Liu, P. Chen, H. Chen, M. Li, and M. Xie, 2018: Interaction between the black carbon aerosol warming effect and East Asian monsoon using RegCM4. J. Climate, 31, 9367-9388, https://doi.org/10.1175/JCLI-D17-0767.1. 